\title{
Strategy for College English Education to Combine with Regional Economic --Taking Guanzhong Area, Shaanxi Province as an Example
}

\author{
Yan Fang \\ Xi'an Siyuan University Shaanxi, China, 710038
}

Keywords: College English education; Regional Economic; Strategy

\begin{abstract}
With the continuous strengthening of China's economic construction, trade exchanges and international conferences between countries have become more and more frequent. Economic development determines language demand. Under the development trend of economic globalization, college English education has played an important role in regional economic construction, which can provide more interdisciplinary English professionals and promote the development of local regional economy. So, it is necessary to pay more attention to college English education and create an English education mode which is combined with regional economic development, according to the talent demand of local economic construction. Based on the perspective of economic globalization, this paper analysis the necessity of combining college English education with regional economic development. This paper puts forward the strategy for college English education to be combined with regional economic.
\end{abstract}

\section{Introduction}

With the increasing trend of economic globalization, English has become the only recognized international language in the world. In view of Chinese current economic development, there are many forms presenting a good situation that the country is rich and the people are strong, such as "regional economic circle", "local economy", "urban agglomeration of economic development", etc. Without English as a bridge of international communication, China cannot learn advanced experience from developed countries better. So, China does not have today's economic development speed and construction results. The rapid development of China's economy is in urgent need of high-level English talents. At the same time, advanced English talents are increasingly promoting the development of the whole regional economy. Practice has proved that a country's economic level, on the one hand, depends on the abundance of material resources. On the other hand, it depends on high-quality talents. However, English education provides the necessary international information and technical guarantee for economic development. 


\section{The interaction between English education and regional economic development}

\subsection{English education promotes regional economic development}

\subsubsection{Promote import and export trade in regional economies}

These foreign-related economic activities are inseparable from foreign languages, especially English, such as building an export-oriented economic system, undertaking foreign industrial transfer, and so on. Which determines the importance of English education in regional economic development. English learning should not only learn language knowledge, but also learn the cultural background, customs, etiquette, and so on. Only in this way can people with different cultural backgrounds and values develop harmoniously in the same economic activity, and then promote export - oriented regional economy thereby.

\subsubsection{Promote the transformation of economic models}

Only by strengthening English education in this region can high-quality application-oriented talents be trained. Talent is necessary to make investment in the region more attractive. So, excellent English application talents can effectively learn and introduce foreign advanced management experience and production technology, which is helpful to improve the quality of products. Excellent English application-oriented talents can also improve the quality of employees in this region, which is helpful for promoting foreign business cooperation and market diversification. Which will help transform the economic growth model of Shaanxi province.

\subsubsection{Promote the development of tourism}

Shaanxi province is rich in tourism resources, such as Terracotta warriors and horses, Shaanxi history museum, Wild goose pagoda, Ancient city wall, the forest of steles, the academy door, Bell tower, and so on. These famous scenic spots are international high-quality tourist resources, which need a large number of foreign language talents for international tourists. At the same time, excellent foreign language talents attract a large number of overseas tourists. The exchange of languages greatly promoted the economic development.

\subsection{Regional economic development promotes English education}

\subsubsection{Provide financial support for English education}

At present, the funds of colleges and universities in China generally come from local financial appropriations. So, the higher the level of regional economic development is, the higher the fiscal revenue will be, and the region's investment in education will increase. The more developed the regional economy is, the higher the demand for talents and technology will be. So, enterprises will take the initiative to seek cooperation or joint education with universities. Through the financial support of enterprises, colleges and universities have strengthened their educational strength.

\subsubsection{Expanded the market of English education students}

With the continuous development of Chinese economy, education funds for children are also increasing. More and more parents are willing to let their children accept careers. In addition, with the improvement of regional economic development level, the requirements for practitioners are constantly improved, such as knowledge ability, skill level and English application ability. In addition, there are many people who intend to study and work abroad, so that they have the 
requirements of re-education and retraining, thus providing a source market for higher English education.

\subsubsection{Expanded the English education job market}

With the development of regional economy, the industrial structure has been constantly adjusted. Some old labour-intensive industries are gradually being replaced by technology-intensive ones. Which has led to changes in the structure of employment. Export-oriented regions have an increasingly urgent need for English application-oriented talents, which objectively increases the demand of enterprises for graduates with strong English application ability. This demand has increased the employment opportunities and expanded the employment market for graduates. So, the developing regional economy expanded the colleges and universities. Regional economy promotes the development of higher education, thus driving the development of English education.

\section{The necessity of combining English education with regional economic development}

In a modern economy, education investment is seen as the "engine" of economic growth. In "the wealth of nations", the capital value of education is elaborated in detail. In recent years, developing countries began to pay attention to investment in education, so their economic growth rate began to rise significantly. Thus, education investment has a significant impact on economic growth. English education has been applied in political, economic, social and other fields. English has been used in various economic construction and social undertakings. English has been used in various economic construction and social undertakings. It can transfer foreign science and technology to China through English translation, so as to achieve mutual communication, mutual understanding, mutual negotiation and cooperation. With the rapid development of economic globalization, its application field and scope will be increasingly expanded. English education will also play a significant role in promoting regional economic development.

Regional economic integration promotes economic development and trade exchanges, as well as the internationalization of education. English education internationalization has become a crucial link, which plays a key role in social economy and talent cultivation quality. Regional economic development brings advantages to English education, and English education also provides strong impetus for local economic development. English education takes advantage of regional resources to adopt integrated talent training mode, such as professional quality, English language skills, professional skills and practical application. We must adhere to the concept that English serves the economy and regional economy transports English application-oriented talents, so as to realize the combined development.

\section{Development strategy of combining English education with regional economic}

\subsection{Government-led cooperation}

In order to promote the sustainable economic development of Shaanxi province, education and scientific research resources should be integrated to realize resource sharing. Only in this way can we give full play to the advantages of Shaanxi province universities in scientific research. Under the guidance of the government, the environment for technological innovation should be created to promote the coordinated development of English talent cultivation and regional economy. The government will integrate the resources in Shaanxi province to create an English talent pool. In this way, a resource network can be formed. Which will help English talents to provide a more fair and just platform. At the same time, the government plays a leading role in promoting the status of 
English talents in society. In this way, college students can not only pay attention to the improvement of comprehensive English ability, but also promote the economic development of Shaanxi province.

\subsection{Building a sound contingent of specialized teachers}

English teacher specialization is an inevitable requirement for English teaching to coordinate regional economic development. At present, college English teachers have a good understanding of English language knowledge and basic skills, but they do not understand the professional knowledge and corresponding professional English well. With the continuous improvement of students' English ability, it is necessary to build up a "double-teacher" teaching team with good English and strong specialty. First, we should develop a set of training programs and ensure their effective implementation with the reward and punishment system. Second, teachers should regularly attend relevant professional training and practice. Schools should engage teachers in the forefront of production and exercise their practical ability. The double-teachers should take advanced courses, such as accounting, tourism and hotel, etc. And encourage them to take an accounting certificate and tourist guide pass. After mastering the relevant professional knowledge, the double-teachers will impart tourism English more accurately and vividly. Which is helpful for improving the quality of teaching and professionalism in the classroom.

\subsection{English education effectively connects with regional industrial structure}

Higher English education should be effectively connected with the adjustment of regional industrial structure. Quickly train a large number of English professionals. Such as, the tourism industry needs a lot of professional tourism service talents with intercultural communication ability and marketing talents with professional English skills. Colleges and universities should take the demand of talents as an opportunity to conduct in-depth cooperation with enterprises, which is of great help to the cultivation of English talents in colleges and universities. In terms of college English education, many college students find their lack of English ability in practical work. Through the internship in enterprises, English students have improved their comprehensive English ability. Realizing the effective connection between education and regional economy promotes the development of both.

\subsection{The change of college talent cullivation mode}

Talent cultivation is one of the important responsibilities of colleges and universities. Different times have different standards and requirements for talents. So, the mode of talent cultivation in colleges and universities should adapt to the development of regional economy. Talent cultivation in colleges and universities has changed from "elite" education to "public" education, but this change cannot meet the special talent needs of enterprises. So, the transformation from high-end technical to high-quality applied talents has become the mainstream. The education mode of college English needs to be adjusted appropriately, only in this way can it adapt to the regional economic development. The cultivation mode of English students changes mainly through the following two points. First, strengthen the practical ability of English majors. Colleges and universities need to include practical ability examination into the assessment system and strengthen the weight of indicators. Second, give more practical opportunities to college students through school-enterprise cooperation. Based on the demand of regional economic development for English talents, English practice is taken as an important basis for selecting cooperative enterprises. 


\section{Conclusions}

English education plays an important role in promoting the regional economy development, and the regional economy development will also affect the adjustment of English education goals and models. We should combine the actual situation of regional economy to carry on the reform of English education continuously. Only in this way, with the rapid development of regional economy, can we meet the demand of social development for English.

\section{References}

[1] Yao hong. Research on education development of yueyang regional economy and higher vocational colleges [J]. Dongting lake development BBS anthology. 2011, (10):76.

[2] Vaillancourt F, Grin F. The choice of a language of instruction: The economic aspects: Distance learning course on language instruction in basic education [M]. Washington, DC: World Bank Institute, 1991.

[3] Ye ling. Research on countermeasures of education service regional economic development in higher vocational colleges -- a case study of hunan province [J]. Adult education, 2013. (01): 60

[4] Miao yaohua, lian junying. Research on the interaction between regional economy and education [f]. Journal of Beijing institute of industrial technology, 2011, (02):26-28 